\title{
The Essence and Application of the Optical Absorption Method for Quantitative and Qualitative Analysis of Radiation Defects in Optical Crystals
}

\author{
Ye.E. Lobanov \\ O.M. Beketov National University of Urban Economy in \\ Kharkiv, Ukraine \\ E-mail: lobanov.kh@gmail.com
}

\section{O.M. Petchenko}

O.M. Beketov National University of Urban Economy in Kharkiv, Ukraine

E-mail: ompet@ukr.net

\begin{abstract}
Today ionic crystals are widely used in devices for various purposes. In X-ray spectral optics they are widely used as crystal monochromators; ionic crystals are used in optical devices where lenses and transparent optical media (light filters) are made of optically pure materials - ionic crystals. In general, the main positive feature of these materials is transparency regarding the transmission of radiation in the visible region of the spectrum (transmittance of about 0.9) and neutrality - that is, approximately the same reaction of the medium to different spectral ranges of radiation.
\end{abstract}

Ionic crystals are also widely used in detectors (scintillators, ionizing radiation dosimeters) and lasers. They are also widely used in acousto-optics and electrical engineering (lines of electrical signals delay, which gain efficiency due to the relatively small absorption of ultrasonic waves, and, therefore, it is possible to work with a wide sequence of signals probing the crystal). It is known that when ionizing radiation passes through ionic crystals, color centers appear in them, which can change the spectral composition of radiation both in the $U V$ region and in the visible range. For example, the simplest configurations of color centers ( $F$-centers) lead to the appearance in optical materials of additional absorption bands localized on the wavelength axis with a maximum at the wavelength $\lambda_{\max }=$ 248 Hм , but more complex configurations of radiation damage in solids already lead to the appearance of absorption bands at wavelengths in the visible range.

This already presents some difficulties for developers and designers of relevant equipment, as changes in the spectral composition of radiation passing through the optical system of the device can lead, for example, to loss of efficiency of the selected radiation receiver, the main characteristic of which is primarily spectral sensitivity. Taking into account possible changes in the spectral composition of radiation is an important and urgent task of modern optical instrumentation.

The purpose of this work is the analysis and justification of a method that takes into account structural changes in externally irradiated ionic crystals.

\author{
G.I. Nikitsky \\ "LLC RPE LTU" \\ Ukraine \\ E-mail: gdaeron@ukr.net
}

\author{
G.O. Petchenko
}

O.M. Beketov National University of Urban Economy in Kharkiv, Ukraine

E-mail: gdaeron@ukr.net

Keywords - ionic crystals, color centers, optical absorption method, transmittance, volume concentration of F-centers, attenuation spectral index, optical absorption bands, refractive index, reflection coefficient, radiation flux.

\section{OPTICAL FUNCTIONAL MATERIALS, THEIR APPLICATION IN DEVICES}

It is known today [1-8] that ionic crystals have found wide application in optics (crystal monochromators in Xray spectral optics, lenses, transparent optical media (light filters) of optical instruments), in detector and laser technology. It is known that when ionizing radiation passes through ionic crystals, color centers appear in them, which can change the spectral composition of radiation both in the UV region and in the visible range. Quantitative and qualitative analysis of such radiation damage to optical crystals is a source of information that must be taken into account when designing elements, devices and systems based on them.

The purpose of this review is a detailed consideration of the optical absorption method, justification of the choice of relations for the calculation and conditions of their use.

\section{ESSENCE AND JUSTIFICATION OF THE ABSORPTION OPTICAL METHOD}

The essence and application of the absorption optical method for quantitative and qualitative analysis of defects of radiation origin in solids are described in [1-8]. Articles [1-8] demonstrate the results of using the method for the study of radiation defects in ionic crystals.

It is known [1] that color centers are formed in ionic crystals under the influence of radiation. When radiation acts on a crystal, the radiation energy is spent mainly on electronic excitations and only to a small extent on the interaction with the nuclei of atoms of matter, due to which F-centers (electrons in anionic vacancies) appear. (For example, the vacancy of fluorine, which captured the 
electron - a known model of a stable F-center for LiF [1]) With increasing concentration of F-centers it becomes possible to combine them into more complex configurations (two or three F-centers form M-centers and R-centers) [1].We also know about FA-centers (which occur when a certain part of the cations in the crystal is replaced by cations of another alkali metal) and VK centers (which occur when vacancies are captured by defects of the structure) [1]. Each of the types of color centers has frequency localization of the absorption bands characteristic of this crystal.

A well-known absorption method is used to identify and analyze existing defects of radiation origin in ionic crystals [1-8].

For this purpose, the optical absorption spectra of the crystals before and after irradiation are measured and compared with each other. The indicator of the appearance of color centers in the crystals are the absorption bands, which are the regions of nonmonotonic behavior of the curves $\tau \lambda(\lambda)$ of the spectral transmittance $\tau \lambda$ from the wavelength $\lambda$.. The localization of these bands $\lambda$ max on the wavelength axis gives an answer to what type of color centers are available (since each of the types is characterized by a clear value of wavelength [1]). The concentration of these centers is determined quite correctly by the shape of the absorption band (its half-width, which is its width at half-height [1]).

Similar experiments are also widely used to predict the bandwidth of optical devices in the radiation field when checking the radiation resistance of device elements [1].

To obtain information about the number of color centers in the crystal, which arose under the action of its irradiation, the dispersion ratio of Smakula [4] is used, which makes it possible to determine the bulk density of F-centers by the parameters of the absorption bandwidth. Note that although the theory of Smakula [4] was built in the 30 s of last century in the framework of classical electrodynamics, its result was absolutely correct. This conclusion was reached by D. Dexter [6], who in order to test the theory [4] investigated this problem in the framework of quantum electrodynamics, taking into account both the Lorentz and Gaussian forms of the absorption band.

According to the theory [4], the number of color centers in the crystal can be determined by the following dispersion ratio:

$$
N_{F}=\frac{A^{*}}{f^{*}} \cdot \frac{n}{\left(n^{2}+2\right)^{2}} \cdot K_{m} \cdot \Delta E
$$

where $A^{*}=1,31 \cdot 1017$ is the numerical coefficient valid for the Lorentz shape of the absorption band, $\mathrm{f}^{*}$ is the oscillator power (which is 0.8 for the Lorentz shape of the band $[4,7,8]), \mathrm{n}-$ is the refractive index of the unexcited (unirradiated) crystal in the region $\lambda \max , \mathrm{Km}-$ is the maximum value of the attenuation index, $\Delta E_{-}$is the halfwidth of the band, which is determined by the width of the absorption line at its half-height $[7,8]$.
To determine the parameters of $\mathrm{Km}$ and $\Delta E$ we use the ratios valid for the case of light transmission (radiation) through a plane-parallel layer of liquid and the data of works [9-10].

Consider (see Fig. 1) the luminous flux of radiation (the same is for the flux of energy radiation), passing through a crystalline sample (plane-parallel layer of liquid) [9-10].

Let $\Phi 0$ be the primary flux incident on the crystal surface (see Fig. 1). If we assume that the reflection coefficient from the front and rear faces of the crystal are the same and are $\rho^{*}$, then the flux reflected from the front face of the sample will be $\Phi_{\rho 1}=\rho^{*} \cdot \Phi_{0}$. Then the flow entering the crystal through its front face will be

$$
\Phi_{1}=\Phi_{0}-\rho^{*} \cdot \Phi_{0}=\Phi_{0}\left(1-\rho^{*}\right)
$$

The flux passing through the entire plane-parallel layer of the crystal, which formed the optical path for radiation $\ell$, approaching the back face, will weaken according to Bouguer's law:

$$
\Phi_{2}=\Phi_{1} \cdot e^{-k \ell}=\Phi_{0}\left(1-\rho^{*}\right) \cdot e^{-k \ell}
$$

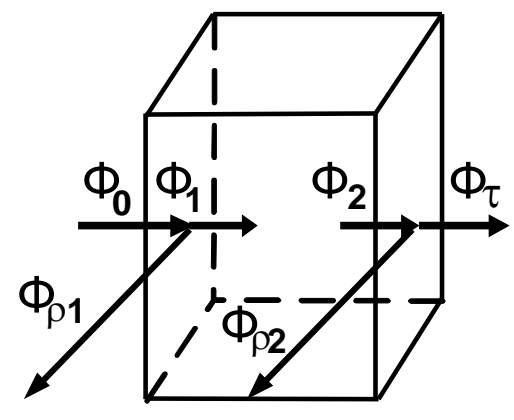

Fig.1. Scheme of radiation transmission through the crystal

The flow reflected from the 2 nd face will be:

$$
\Phi_{\rho 2}=\rho^{*} \cdot \Phi_{2}=\Phi_{0} \cdot \rho^{*} \cdot\left(1-\rho^{*}\right) \cdot e^{-k \ell}
$$
be:

The stream exiting the second face of the crystal will

$$
\Phi_{\tau}=\Phi_{2}-\Phi_{\rho 2}=\Phi_{0}\left(1-\rho^{*}\right)^{2} \cdot e^{-k \ell}
$$

Transmittance:

$$
\tau=\frac{\Phi_{\tau}}{\Phi_{0}}=\left(1-\rho^{*}\right)^{2} \cdot e^{-k \ell} .
$$


Ye.E. Lobanov, G.I. Nikitsky, O.M. Petchenko, G.O. Petchenko Вип.59, №03.

In this formula, according to Frenel's law, $\rho^{*}=\left(\frac{n-1}{n+1}\right)^{2}$

- is the reflection coefficient, $\mathrm{K}$ is the attenuation index, $\ell$ - is the optical radiation path in the sample. In the case, for example, the calculation of the transmittance for lithium fluoride crystals, in which $\mathrm{n}=$ $1.42[7-8]$ in the region of $\lambda \max =248 \mathrm{~nm}$, taking into account the Frenel loss on reflection $\left(1-\rho^{*}\right)^{2}=0.94$, we obtain:

$$
\begin{aligned}
& \tau=0,94 \cdot e^{-k \ell} \Rightarrow \log \left(\frac{0,94}{\tau}\right)= \\
& =K \cdot \ell \cdot \log e \Rightarrow K=\frac{2,3 \cdot \log \left(\frac{0,94}{\tau}\right)}{\ell}
\end{aligned}
$$

Thus, knowing $\tau \lambda(\lambda)$ and the thickness of the crystal, we can find $K \lambda(\lambda)$.

It should be noted that article [9] gives, strictly speaking, a more accurate formula for determining the parameters $\mathrm{Km}$ and $\Delta E$. If we take into account multiple reflections in the crystal, not limited, as done above, to one component of the flow reflected from the back face of the crystal, the final ratio, which we took in the form (3), will change slightly [9]:

$$
\begin{aligned}
& \tau=\left(1-\rho^{*}\right)^{2} \cdot e^{-k \ell}+\rho^{* 2}\left(1-\rho^{*}\right)^{2} \cdot e^{-3 k \ell}+\ldots= \\
& =\frac{\left(1-\rho^{*}\right)^{2} \cdot e^{-k \ell}}{1-\rho^{* 2} \cdot e^{-2 k \ell}}
\end{aligned}
$$

However, Gurevich himself [9] notes, analyzing the limits of acceptability of the first approximation (3), that the strict form, taking into account the full transmittance of the plane-parallel sample (taking into account multiple reflections), strictly speaking, should be used only for $\rho_{*}$ exceeding tens percent (plane-parallel plates of germanium, silicon), and for small $\rho_{*}$ (as for ionic crystals) it is permissible to use relation (3).

The half-width of the absorption band of optical radiation by the test medium can be determined by the formula [10]:

$$
\Delta E=1241 \cdot\left(\frac{1}{\lambda_{1}}-\frac{1}{\lambda_{2}}\right),
$$

where $\lambda 1$ and $\lambda 2$ are known from the experiment limit values of the absorption band.
According to the results of calculations in the relations (5), (4) and (1) it is possible to determine the volume concentration of color centers in the crystal, which arose under the action of its irradiation. Acoustic methods that allow to study the defective structure of crystals in another independent way, despite its hypersensitivity to structural defects [11-15], do not allow to analyze the nature of defects of radiation origin.

\section{CONCLUSIONS ON THE WORK}

The optical absorption method is analyzed in detail, which allows to perform quantitative and qualitative analysis of defects of radiation origin in optically pure crystals. The substantiation of the used relations is given, which allows to calculate the spectral index of attenuation of radiation passing through the optical medium (lens, light filter, etc.) and to correctly determine the volume concentration of color centers in the studied functional materials.

\section{IV. ЛITЕРАТУРА}

[1] V.M. Lisitzyn. Radiation solid state physics. Tomsk: "Izdatelstvo Tomskogo Politekhnicheskogo Universiteta", 2008, 172 p. (in Russian).

[2] M.V. Galustashvili, M.G. Abramishvili, D.G. Driaev, V.G. Kvachadze. Effect of magnetic field on the radiation hardening LiF crystals // FTT. 2011, N 53(7), p. 1340-1342.

[3] T. Klempt, S. Schweiser, K. Schwartz, et al. Magnetic resonance unvestigation of the dynamics of F centers in LiF // Solid State Communications. 2001, N 119, p. 453-458.

[4] A. Smakula. Uber Erregung und Entfarbung lichtelektrisch leitender Alkalihalogenide // Z. Physik. 1930, N 9-10 (59), p. 603614.

[5] A. Smakula, P. Avakian. Color centers in cesium halide single crystals // Phys. Rev. 1960, N 6, p. 2007-2014.

[6] D.L. Dexter. Absorption of light by atoms in solids // Phys. Rev. 1956, N 101, p. 48-55.

[7] G.A. Petchenko, S.S. Ovchinnikov. Effect of the preliminary deformation and irradiation on the optical absorption in LiF crystals // Problems of Atomic Science and Technology. Series "Physics of Radiation Effect and Radiation Materials Science". 2014, N 2(90), p. 29-33.

[8] G.A. Petchenko, A.M. Petchenko. Dependence of electronic color center concentration on the state of irra-diated LiF crystal dislocation structure // Problems of Atomic Science and Technology. Series "Physics of Ra-diation Effect and Radiation Materials Science". 2015, N 2(96), p. 25-28.

[9] M.M. Gurevich. Photometry (Theory, methods and devices), L.: "Ehnergoatomizdat", 1983, 272 p.

[10] V.V. Meshkov, The basics of lightning engineering, M.: «Energiya», 1979, 368 p.

[11] A.M. Petchenko, G.A. Petchenko. Features of resonance absorption of longitudinal ultrasound in strained crystals $\mathrm{KBr}$ at temperature variations // Functional Materials. 2007, V. 14, № 4, P. $475-479$

[12] G.A. Petchenko, A.M. Petchenko. Effect of crystal pre-straining on phonon damping of dislocations // Functional Materials. 2008, V. 15 , № 4, P. $481-486$.

[13] O.M. Petchenko, G.O. Petchenko. Phonon drag of dislocations in $\mathrm{KCl}$ crystals with various dislocation structure states // Ukrainian journal of physics. 2010, V. 55, №. 6, P. $716-721$.

[14] R. Truell, Ch. Elbaum, B. Chik. Ultrasound methods in solid state physics. Moskva: "Mir", 1972. 307 p.

[15] A.A. Botaki, A.A. Vorobev, V.A. Ulyanov, Radiation physics of ionic crystals, M.: Atomizdat, 1980. -208 p. 


\section{Сутність та застосування оптичного абсорбційного методу для проведення кількісного і якісного аналізу радіаційних дефектів у оптичних кристалах}

\author{
Є.Е. Лобанов \\ Харківський національний університет міського \\ господарства імені О.М. Бекетова, \\ Україна \\ O.М. Петченко \\ Харківський національний університет міського \\ господарства імені О.М. Бекетова, \\ Україна
}

\author{
Г.І. Нікітський \\ ТОВ "НВП "ЛТУ", \\ Україна
}

Г.О. Петченко

Харківський національний університет міського господарства імені О.М. Бекетова, Україна

На сьогоднішній час іонні кристали широко застосування в приладах різного призначення. У рентгеноспектральній оптиці їх широко використовують як кристал-монохроматори, в оптичних приладах застосовуються лінзи і прозорі оптичні середовища (світлофільтри), зроблені з оптично чистих матеріалів - іонних кристалів. Загалом, головна позитивна риса цих матеріалів - прозорість щодо проходження випромінювання у видимій області спектра (коефіціснт пропускання близько 0,9) і нейтральність - тобто, приблизно однакова реакція середовища на різні спектральні діапазони випромінювання. Іонні кристали також широко використовуються у детекторній техніці (сцинтилятори, дозиметри іонізуючого випромінювання) і лазерах. Також відоме їх широке застосування у акустооптиці і електротехніці (лінії затримки електричних сигналів, які набувають ефективності через порівняно незначне поглинання УЗ-хвиль, i, відтак, с можливість працювати 3 широкою послідовністю зондуючих кристал сигналів). Відомо, що при проходженні іонізуючого опромінення через іонні кристали, в них виникають центри забарвлення, які можуть змінювати спектральний склад випромінювання як у УФ-області, так і у видимому діапазоні. Наприклад, найпростіші конфігурації центрів забарвлення (F-центри) призводять до появи у оптичних матеріалах додаткових смуг поглинання, що локалізуються на осі довжин хвиль із максимумом на довжині хвилі $\lambda_{\text {max }}=248$ нм, але більш складні конфігурації радіаційних пошкоджень в твердих тілах вже призводять до виникнення смуг поглинання на довжинах хвиль, що знаходяться у видимому діапазоні. Це вже представляс певні складнощі для розробників і проектувальників відповідного обладнання, так як зміна спектрального складу випромінювання, що проходить через оптичну систему приладу може призвести, наприклад, до втрати ефективності вибраного приймача випромінення, головною характеристикою якого с, в першу чергу, спектральна чутливість. Урахування можливих змін у спектральному складі випромінювання - важлива і актуальна задача сучасного оптичного приладобудування. Мета даної роботи - аналіз і обгрунтування методу, який враховус структурні зміни у опромінених зовні іонних кристалах.

Ключові слова - іонні кристали, центри забарвлення, оптичний абсорбційний метод, коефіцієнт пропускання, об’ємна концентрація F-центрів, спектральний показник ослаблення, смуги оптичного поглинання, показник заломлення, коефіцієнт відбиття, потік випромінювання. 